К. В. Данова

Харківський національний університет міського господарства ім. О. М. Бекетова, Харків, Україна

\title{
АНАЛІЗ ФУНКЦІОНАЛЬНИХ СТАНІВ ЛЮДИНИ-ОПЕРАТОРА З ІНВАЛІДНІСТЮ У КОНТЕКСТІ ЗАБЕЗПЕЧЕННЯ БЕЗПЕКИ ПРАЦІ
}

\begin{abstract}
Анотація. Актуальність. Ефективне використання трудового потенціалу є важливим у забезпеченні сталого розвитку підприємництва України, підвищення рівня його конкурентоспроможності та інвестиційної привабливості. У ситуації відтоку кадрів з металургійної, машинобудівної та інших галузей економіки, активізація та включення трудового резерву у виробничі процеси $\epsilon$ необхідною передумовою розвитку економіки регіонів України. Одним з напрямів реалізації цього підходу є створення інклюзивного виробничого середовища та залучення на робочі місця працівників із інвалідністю. Важливу роль при цьому відіграє розробка та реалізація організаційно-технічних рішень по адаптації робочих місць та трудових процесів під можливості працівників із інвалідністю. Прийняття управлінських рішень стосовно адаптації робочих місць та урахування фізичного й психічного стану працівника мають грунтуватися на вивченні особливих потреб осіб із інвалідністю $з$ метою попередження погіршення стану їх здоров’я та створення травмонебезпечної ситуації на робочому місці. Мета. Метою статті $є$ аналіз особливостей функціональних станів людини-оператора із інвалідністю задля підвищення рівня ефективності та безпеки системи «людина - машина - виробниче середовище». Методика дослідження. Методика грунтується на аналізі функціональних станів осіб із інвалідністю у контексті ефективності та безпеки трудового процесу із застосуванням теорії ланцюгів Маркова для отримання математичних залежностей, що описують ймовірність знаходження людини-оператора з інвалідністю на певному рівні трудової активності. Наукова новизна. Полягає у розробці наукового підходу для дослідження функціональних станів працівника із інвалідністю задля попередження виникнення нещасного випадку чи створення аварійної ситуації на підприємстві. Практичне значення. Отримані математичні залежності дозволяють визначити ймовірність переходу працівника із інвалідністю у певний функціональний стан за наявності деградаційних процесів у системі «людина - машина - виробниче середовище», які можуть призвести до травматизму на робочому місці, а також процесів, що стабілізують систему та підвищують рівень безпеки. Це дає можливість визначити пріоритетні шляхи щодо вдосконалення стану охорони праці на робочому місці.
\end{abstract}

Кл юч ов і слов а : працівник із інвалідністю, безпека, функціональний стан, ланцюги Маркова.

\section{Проблема та її зв'язок з науковими та практичними завданнями}

Розвиток економіки безпосередньо пов'язаний із активізацією та включенням трудового потенціалу у виробничі процеси. Ефективне використання трудового резерву забезпечує сталий розвиток будьякого підприємства, його конкурентоспроможність та інвестиційну привабливість. Складна соціальноекономічна ситуація в країні обумовлює відтік кваліфікованих кадрів та нестачу трудових ресурсів у сфері виробництва.

За статистикою останніми роками спостерігається тенденція до зниження чисельності осіб, зайнятих у металургійній та машинобудівній сферах: у 2014 р. на металургійних підприємствах працювало 268,2 тис. осіб, а у 2018 р. - 193,6 тис. осіб; у сфері виробництва машин і устаткування чисельність працівників зменшилася 3 354,7 тис. осіб до 304,5 тис. осіб [1]. У той же час спостерігається зростання кількості вакансій професіоналів, фахівців та кваліфікованих робітників, які працюють із інструментом.

Нестача кадрів призводить до зниження темпів розвитку економіки, зокрема у металургійній та машинобудівній сферах, які традиційно вважаються одними з пріоритетних напрямів розвитку економіки України.

У такій ситуації важливим питанням $є$ реалізація програм, спрямованих на збереження трудових ресурсів та залучення на робочі місця трудові резер- ви, які наразі залишаються поза сферою виробничої діяльності. Зараз в Україні налічується близько 2,5 млн. осіб із інвалідністю, при тому, що рівень їх трудової зайнятості складає близько 0,6 \%. Структура інвалідності населення України виглядає наступним чином (рис. 1) [1].

3 представлених даних видно, що 36 \% - особи iз інвалідністю II групи, 55 \% - особи III групи інвалідності, які можуть бути задіяні у виробничому процесі у різних сферах економіки. Крім того, спостерігається тенденція до зростання чисельності осіб із інвалідністю серед дітей, які зараз внаслідок розвитку інклюзивного навчання мають можливість отримати повноцінну освіту та у подальшому реалізувати себе у професійній діяльності.

У вирішенні питання залучення осіб із інвалідністю на робочі місця важливу роль відіграє створення належних умов праці та адаптація робочих місць під можливості працівників із інвалідністю.

Розробка ефективних адаптаційних рішень базується на вивченні особливостей функціонального стану працівника із інвалідністю. Врахування існуючих обмежень життєдіяльності осіб із інвалідністю та створення відповідних цим потребам умов праці дозволяє сформувати інклюзивне виробниче середовище та підвищити ефективність використання трудових ресурсів.

Аналіз досліджень і публікацій. Функціональний стан людини, яка виконує операторські дії, у значній мірі обумовлює ефективність та безпеку трудових процесів. 


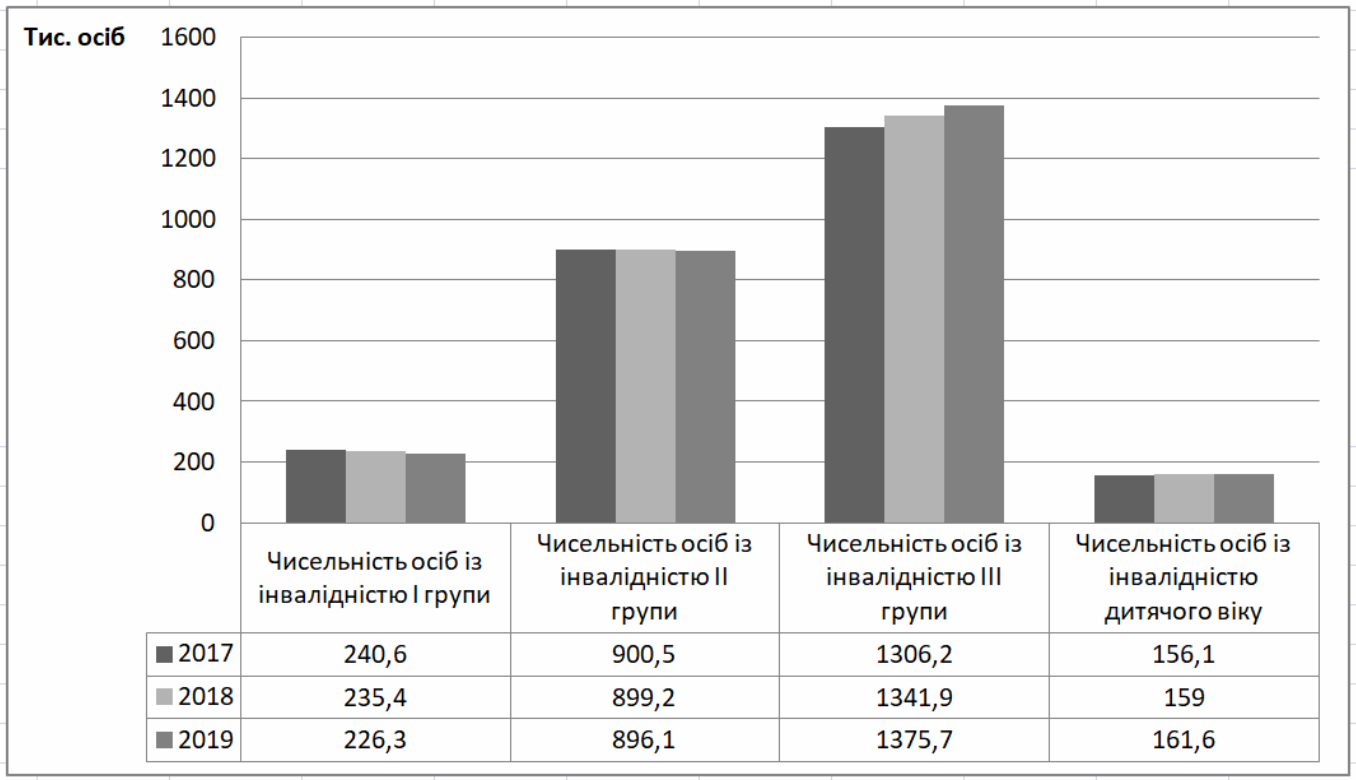

Рис. 1. Структура інвалідності населення України

Оцінка функціонального стану працівника без стійких порушень у стані здоров'я дозволяє розробити заходи щодо оптимізації трудового процесу з метою підвищення його ефективності.

У той же час дослідження функціонального стану особи із інвалідністю $\epsilon$ необхідною умовою забезпечення як ефективності, так й безпеки праці на робочому місці [2].

У роботі [3] зазначається, що функціональний стан працівника $€$ інтегральним показником його працездатності, що визначається індивідуальними особливостями, факторами виробничого середовища та трудового процесу.

Вплив індивідуальних особливостей на рівень безпеки обумовлюється рядом характеристик, основними 3 яких є: психофізіологічні характеристики людини; досвід, рівень освіти, професійні навички і способи виконання роботи; вік; тяжкість і напруженість праці, що впливають на накопичення втоми. В роботі [4] на базі аналізу впливу факторів трудового процесу на рівень травматизму зроблено висновок про переважання наступних причин: напруженості праці, обумовлена необхідністю забезпечення високого рівня продуктивності, втома. Для працівників із інвалідністю ці причини набувають особливої актуальності внаслідок наявності стійких функціональних змін у стані здоров'я.

Відсутність ефективних механізмів щодо попередження реалізації небезпек, пов'язаних $з$ людським фактором, призводить до збільшення ризику отримання травми і інших несприятливих наслідків.

В роботі [5] підкреслюється, що, незважаючи на значну вразливість працівників 3 інвалідністю, вони частіше працюють в несприятливих умовах, що збільшує ризик травматизму. Тому роботодавці повинні розробляти і впроваджувати чіткі процедури щодо зниження ризику травматизму працівників з інвалідністю із урахуванням їх функціонального стану.

Мета дослідження. Дослідити стани людиниоператора у системі «людина - машина - навколиш- нє середовище», який має стійкі функціональні зміни у стані здоров'я, з метою розробки методів управління працездатністю та забезпечення належного рівня безпеки на робочому місці.

\section{Викладення матеріалу та результати}

У контексті трудового процесу та вимог безпеки можна виділити наступні функціональний стани людини-оператора із інвалідністю (рис. 2):

1) працездатний стан $S_{I}(t)$ - коли робоче місце та трудовий процес повністю враховують обмеження життедіяльності працівника і дозволяють забезпечити рівень працездатності людини та виконання вимог безпеки на максимальному рівні;

2 ) працеспроможний стан $S_{2}(t)$ - працівник здатний виконувати професійні обов'язки частково; вимоги, обумовлені трудовим процесом та охороною праці, виконуються не у повному обсязі внаслідок наявності невідповідностей між обмеженнями життєдіяльності працівника та роботі, що виконується;

3) стан готовності $S_{3}(t)$ - працівник має потенціал щодо виконання професійних обов'язків (наприклад, після медичної реабілітації), але, внаслідок неналежного рівня імплементування адаптаційних рішень, $є$ недостатньо задіяний у трудовому процесі;

4) стан раптової відмови $S_{4}(t)$ - травма, інше ушкодження стану здоров'я внаслідок впливу факторів виробничого середовища та трудового процесу, які об'єктивно існують на робочому місці чи обумовлені невідповідністю робочого місця й трудового процесу можливостям працівника; 5) непрацездатний стан $S_{5}(t)$ - особа, яка має інвалідність, знаходиться у працездатному віці, але $\epsilon$ виключеною $з$ трудового процесу внаслідок наявності значних функціональних обмежень, викликаних станом здоров'я, а також відсутності адаптаційних рішень, які могли б компенсувати невідповідності стану здоров'я людини вимогам робочого місця та трудового процесу. 


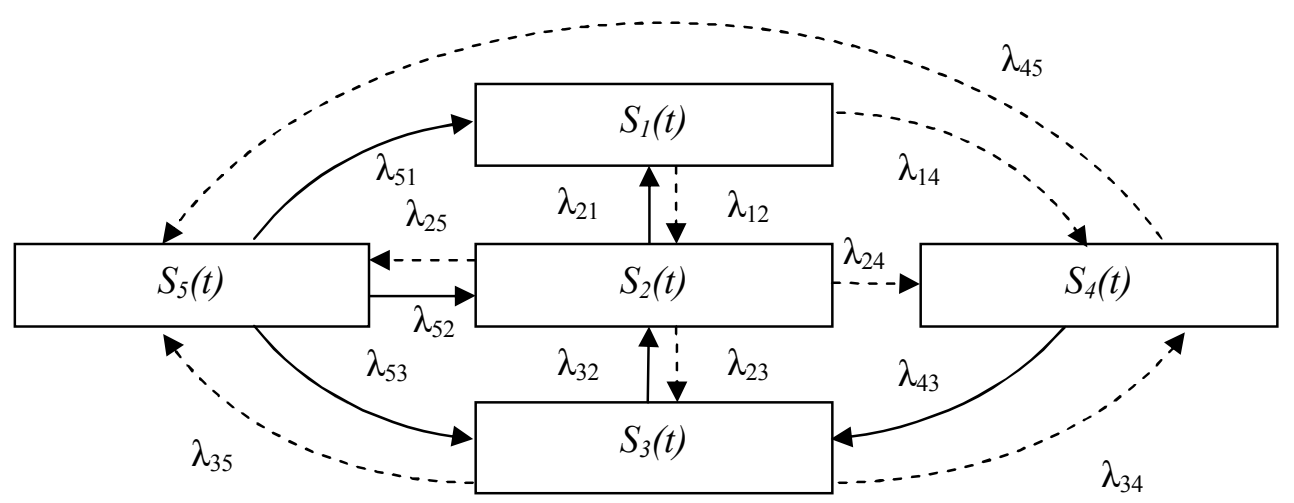

Рис. 2. Граф функціональних станів працівника із інвалідністю

Людина-оператор, яка має обмеження життєдіяльності, в аспекті виконання трудових обов'язків може знаходитися в одному з вищезазначених робочих станах. Для аналізу даних станів зазначимо два початкових (нульових) стани:

$S_{01}(t)$ - набуття стійких функціональних змін у стані здоров'я 3 дитинства, початок трудової діяльності людини відбувався у статусі особи із інвалідністю;

$S_{02}(t)$ - набуття інвалідності внаслідок нещасного випадку чи професійного захворювання на виробництві, або внаслідок травматизму невиробничого характеру.

Ці стани мають враховуватися при розробці та прийнятті управлінських рішень щодо вибору робочого місця для особи, якій встановлено інвалідність, 3 метою максимального врахування індивідуальних особливостей людини. Для цілей даного дослідження вважаємо, що $S_{01}(t)=S_{02}(t)=S_{5}(t)$.

Впровадження ефективних організаційнотехнічних рішень задля переведення функціонального стану працівника із інвалідністю до працездатного є кінцевою метою реабілітаційних та адаптаційних заходів, оскільки такий стан дозволяє забезпечити максимальну ефективність та безпеку працівника, a, отже, матиме вагомий соціальноекономічний ефект:

$$
\begin{gathered}
S_{01}(t) \rightarrow S_{5}(t) \rightarrow S_{3}(t) \rightarrow S_{2}(t) \rightarrow S_{1}(t) ; \\
S_{1}(t) \rightarrow S_{4}(t) \rightarrow S_{02}(t) \rightarrow S_{3}(t) \rightarrow S_{2}(t) \rightarrow S_{1}(t) .
\end{gathered}
$$

Працездатний стан $S_{I}(t)$ для працівника, функціональний стан якого характеризується значними обмеженнями життєдіяльності, може бути ніколи не досягнутий.

Проте, навіть досягнення функціонального стану $S_{2}(t)$ є вагомим результатом у напряму забезпечення безпеки й ефективності трудової зайнятості осіб із інвалідністю.

Перехід 3 одного функціонального стану до іншого може здійснюватися внаслідок деградаційних процесів $D(t)$, які на рис. 1 позначені пунктиром, та процесів, що стабілізують стан $C(t)$ (суцільна лінія).

Деградаційні процеси призводять до зниження ефективності й безпеки праці та здатні спричинити погіршення стану здоров'я працівника із інвалідністю, призвести до травми, аварійної ситуації на об'єкті.

До цієї групи процесів належать:

- недостатній рівень організації трудового процесу;

- незадовільні санітарно-гігієнічні умови праці;

- відсутність чи низький рівень адаптації трудових процесів та робочих місць під можливості працівника із інвалідністю;

- незадовільний психологічний мікроклімат у колективі, брак розуміння важливості працевлаштування осіб із інвалідністю з боку керівництва та ін.

Процесами, що стабілізують ефективність й безпеку праці та сприяють підвищенню їх рівня є:

- належна оцінка рівня працездатності працівника із інвалідністю;

- розробка та впровадження адаптаційних організаційно-технічних рішень, які компенсують вади у стані здоров'я, забезпечують належний рівень працездатності та безпеки праці;

- створення санітарно-гігієнічних умов праці, які б дозволили зберегти стан здоров'я та працездатності працівника із інвалідністю на належному рівні із урахуванням наявних обмежень життєдіяльносTi;

- впровадження заходів по створенню у колективі атмосфери доброзичливості, попереджання дискримінації та ін.

3 метою управління ефективністю й безпекою праці особи із інвалідністю на робочому місці необхідно знати, у якому функціональному стані $S_{i}(t)$ на даний момент знаходиться працівник, та які потрібні управлінські дії, щоб перевести його у інший стан $S_{n}(t+T)$.

Приймаємо:

$P_{i}$ - ймовірність знаходження працівника 3 інвалідністю у певному функціональному стані;

$\lambda_{i j}$ - щільність імовірності переходу [6].

Використовуючи теорію ланцюгів Маркова, запишемо систему рівнянь для визначення ймовірності перебування працівника із інвалідністю у певному функціональному стані $S_{i}(t)$ :

$$
\frac{d P_{1}(t)}{d t}=-\left(\lambda_{12}+\lambda_{14}\right) P_{1}(t)+\lambda_{21} P_{2}(t)+\lambda_{51} P_{5}(t)
$$




$$
\begin{aligned}
\frac{d P_{2}(t)}{d t} & =-\left(\lambda_{21}+\lambda_{23}+\lambda_{24}+\lambda_{25}\right) P_{2}(t)+ \\
& +\lambda_{12} P_{1}(t)+\lambda_{32} P_{3}(t)+\lambda_{52} P_{5}(t) ; \\
\frac{d P_{3}(t)}{d t} & =-\left(\lambda_{32}+\lambda_{34}+\lambda_{35}\right) P_{3}(t)+\lambda_{23} P_{2}(t)+ \\
& +\lambda_{43} P_{4}(t)+\lambda_{53} P_{5}(t) ; \\
\frac{d P_{4}(t)}{d t} & =-\left(\lambda_{43}+\lambda_{45}\right) P_{4}(t)+\lambda_{14} P_{1}(t)+ \\
& +\lambda_{24} P_{2}(t)+\lambda_{34} P_{3}(t) ; \\
\frac{d P_{5}(t)}{d t} & =-\left(\lambda_{51}+\lambda_{52}+\lambda_{53}\right) P_{5}(t)+\lambda_{25} P_{2}(t)+ \\
& +\lambda_{35} P_{3}(t)+\lambda_{45} P_{4}(t) .
\end{aligned}
$$

Задаючи значення щільності ймовірності переходу, виходячи з функціональних обмежень особи із інвалідністю, а також особливостей трудового процесу та виробничого середовища, можна визначити ймовірність знаходження працівника із інвалідністю у певному стані, що дозволить оцінити ефективність адаптаційних рішень щодо підвищення рівня безпеки й ефективності трудової діяльності.

\section{Висновки \\ та напрямок подальших досліджень}

Дослідження функціональних станів працівників, зокрема тих, які мають інвалідність, дозволяє визначити основні шляхи підвищення рівня ефективності трудової діяльності, а також попередження нещасних випадків на робочих місцях.

У статті проаналізовано функціональні стани, у яких може знаходитися людина-оператор із інвалідністю, та за допомогою теорії ланцюгів Маркова отримано рівняння, що характеризують ймовірність знаходження працівника із інвалідністю у певному функціональному стані за наявності деградаційних процесів та впливів, що стабілізують систему «людина - машина - виробниче середовище».

У подальшому дані рівняння можуть використовуватися у дослідженні ефективності заходів по забезпеченню безпеки й ефективності праці.

\section{СПИСОК ЛІТЕРАТУРИ}

1. Праця в Україні у 2018 році / Статистичний збірник // Офіційний сайт Державної служби статистики України [Електронний ресурс] - Режим доступу: http://www.ukrstat.gov.ua/.

2. Данова К.В. Використання ланцюгів Маркова у дослідженні ризиків на робочому місці працівника із інвалідністю / К.В. Данова // Комунальне господарство міст. - Вип. 3 (149). - Х. : ХНУМГ, 2019. - С. 164-168.

3. Лис Ю.С., Солдатов О.В. Функціональний стан людини-оператора в системі управління охороною праці / Ю.С. Лис, О.В. Солдатов // Системи озброєння і військова техніка, 2016, № 3(47). - С. 133-136

4. Newman, S. M., Keefe, R. F., Brooks, R. H., Ahonen, E. Q., \& Wempe, A. M. (2018). Human Factors Affecting Logging Injury Incidents in Idaho and the Potential for Real-Time Location-Sharing Technology to Improve Safety. Safety (Basel, Switzerland), 4(4). P. 43. doi: https://doi.org/10.3390/safety4040043

5. F. Curtis Breslin, A. Morgan Lay, Arif Jetha \& Peter Smith (2018) Examining occupational health and safety vulnerability among Canadian workers with disabilities, Disability and Rehabilitation, 40:18. P. 2138-2143. doi: https://doi.org/10.1080/09638288.2017.1327985.

6. Вентцель Е.С. Исследование операций: задачи, принципы, методология 2-е изд. - М. : Наука, 1988. - 208 с.

Received (Надійшла) 26.02.2020

Accepted for publication (Прийнята до друку) 22.04.2020

\section{Analysis of the functional states of human-operator with disability in the aspect of occupational safety \\ K. Danova}

Abstract. The aim. Effective use of work potential is important in ensuring of sustainable development of entrepreneurship in Ukraine, increasing its competitiveness and investment attractiveness. In a situation of an outflow of personnel from the metallurgical, engineering and other sectors of the economy, the activation and inclusion of the work reserve in production processes is the key to the sustainable development of economic sectors. One of the directions for implementing this approach is to involve the employees with disabilities to the workplaces. An important role in solving this issue is the creation of appropriate working conditions and the adaptation of workplaces to the capabilities of workers with disabilities. Making managerial decisions to adapt workplaces to the capabilities of the employee, taking into account his physical and mental state, should be based on the studying of the characteristics of the conditions of persons with disabilities that are included in the work process in order to prevent the worsening of their health and creation of traumatic situation. The aim of the article is to analyze the features of the functional states of a person-operator with a disability in order to increase the efficiency and safety level of the "man-machine-production environment" system. Research Methodology. The methodology is based on the analysis of the functional states of persons with disabilities in the context of the efficiency and safety of the work process using the Markov chains theory to obtain mathematical dependencies that describe the probability of a person-operator with disabilities staying in a certain functional state. Scientific novelty. It consists in developing a scientific approach to studying the functional conditions of a worker with a disability to prevent an accident or creation of an emergence situation at the enterprise. Practical value. The obtained mathematical dependences make it possible to determine the probability of transitioning of a worker with a disability to a certain functional state in the presence of degradation processes in the "man - machine - production environment" system that can lead to injuries at the workplace, as well as processes that stabilize the system and increase the safety level. This makes it possible to identify priority ways to improve the state of occupational safety at the workplace.

Keywords: worker with disability, safety, functional state, Markov chains. 